\title{
A Perpetual Search for the Idealized Lost Loved Object: An Object-relations Reading of Ian McEwan's Enduring Love
}

\author{
Roohollah Reesi Sistani ${ }^{1}$, Ruzy Suliza Hashim ${ }^{1} \&$ Shahizah Ismail Hamdan ${ }^{1}$ \\ ${ }^{1}$ School of Language Studies and Linguistics, UKM, Malaysia \\ Correspondence: Roohollah Reesi Sistani, School of Language Studies and Linguistics, UKM, Malaysia. E-mail: \\ roohi.sistani@gmail.com
}

Received: July 28, 2014 Accepted: August 28, 2014 Online Published: August 28, 2014

doi:10.5539/res.v6n3p142 URL: http://dx.doi.org/10.5539/res.v6n3p142

\begin{abstract}
This paper attempts to present the journey of mental suffering in Jed Parry, one of the major characters in Enduring Love. In this regard, it is noted that this journey begins and questions the borders of Self and Other in life and boundaries of love. Jed Parry is perceived as a religious fanatic and what comes next is Jed's obsession with Joe and his attempt to convince him that they are in love, and at the same time Joe is preoccupied with the idea that Jed is obsessed with him. We present a close reading of Enduring Love by elucidating some of the psychoanalytical reflections on Jed via the lens of child-mother conceptual theory. Specifically, we explore the psychic anxieties and the influence of this early female figure on Jed's interactions in light of Object Relations Theory of the psychoanalysis attributable to the Fairbairnian, Kleinnian, and Winnicottian analytic traditions. We trace the psychoanalytical origins of Jed's anxieties and tensions into childhood and also highlight a much earlier female (mother) influence. We will show how deprivation from the establishment of a satisfying contact with this primary love object (mother) can wreak havoc in the character's psyche and cause his ego to move towards establishing relations with his internal objects instead of natural, real objects in his external world.
\end{abstract}

Keywords: Ian McEwan, Enduring Love, object relations, psychic anxieties, conflicts, child-mother interaction, maternal deprivation

\section{Introduction}

Enduring Love lends itself to a psychoanalytical reading. The characters in this novel fail to bring a relationship to fulfillment because of their psychological and emotional inadequacies and it is with the aid of the Klein, Fairbairn, and Winnicott's theory of object relations that one is able to pin point the causes for such conflicts and anxieties of these characters and trace that they are the result of a failure to relate satisfactorily to their respective primary caregivers in their early childhood. Many scholars have critically praised and shown McEwan's obsession with portrayals of psychic tensions in his works but they often interpret this obsession in terms of McEwan's private life, his unhappy marriage to his first wife, and the nervous breakdowns that McEwan has experienced (Slay, 1991; Byrnes, 1999; Cowley, 1997; P.H.S., 1997). These psychic issues have often been treated either in an amalgamation of psychoanalytical approaches and not within an organized frame that would reveal the possible connections among them or relied on Freudian studies rather than pre-Oedipal object relations viewpoint. Distancing from McEwan's private life, we demonstrate that the psychoanalytical origins of the psychological complexities in McEwan's selected texts have not been traced back far enough into childhood and also a much earlier primary female object's influence, in particular the mother's, has been neglected. Consequently, scholars, who have worked on McEwan, have mostly provided us with general readings and analyses of his works and they have not shown any engagement to deeper theoretical examinations focusing on a single psychological school. Even where we see psychoanalytic-theory based criticisms, those psychoanalytic themes and concepts are mostly confined to pure Freudian psychoanalysis (Byrness, 1995; Seaboyer, 1997; Vipond, 2008; Sgarlata, 2009; Wilks, 2009; Fitriya \& Khoiri, 2014), or sometimes based on a merger of psychological approaches (Byrnes, 1999; Cameron, 2002; Keating, 2003; Kogan, 2012) and largely have ignored to focus the study on child-mother theory through Object Relational perspective. As a result, the gap is felt in different approaches of literary psychoanalysis in the area.

Enduring Love tells the story of a college professor, who is about to propose marriage to Claire while they are having a romantic picnic when they are interrupted by an accident. A hot air balloon lands in the field behind 
them; the passengers in it are in danger of falling to their death. Joe and a handful of other men run to help. Unfortunately, a man falls to his death. Standing helplessly over his shattered body, Joe meets another rescuer, Jed. After the incident, Joe tries to get back to his routine, but he is unable to forget the tragedy, and he is haunted by feelings of guilt and by ruminations about how things could have been done differently. Jed calls him unexpectedly and they meet up. Jed reveals that he feels a connection to Joe that far exceeds their shared involvement in the hot air-balloon accident. He begins to stalk Joe and insists that Joe is responding favourably to Jed's overtures. Jed's stalking becomes a strain on Joe and Claire's relationship, and this causes the disintegration of Joe and Claire's relationship.

We contend that there are residues and intimations of the relationships as a re-enactment and representation of the primary parent-child interactions in Enduring Love, but a type of relationship which is not immediately palpable, for the reason that it is masked by the main characters of the novel that implicitly support the interpretation of our argument. Moreover, in this novel, the relevance of our argument concerning the exploration of the residues of the primary child-mother relationships of Jed and the impact of these relationships on his current adulthood life is explicitly linked to his present behavioral symptoms that this individual displays during the time he is alone or in contact with another individual. We attempt to illustrate that McEwan in this selected work is psychoanalytically concerned with the theme of primary child-mother love bond implicitly or silent. Therefore, this research attempts to investigate the role of child-mother bonding in Enduring Love. As mentioned before that might appear a little odd as there is no apparent presence of the mother in this novel. Hence, we will focus on what is not apparent - the absent present mother who contributes to Jed's conflicts. The important point is that in literary criticism this issue is not as odd as it may first appear. Regarding this matter, in his reference to one of the most significant and influential literary critics, "Professor Harold Bloom of Yale", Jon Adams states that in literary criticism we need "to be as alert to absence as presence" (Adams, 2004). As a result, "what the narrator excludes is often what the narrator is thinking about, and what's missing from the story is often what the story is trying to tell you" (Adams, 2004).

\section{Conceptual Framework}

This analysis takes a psychoanalytic approach in studying Jed in McEwan's selected novel but differs from other known previous studies by investigating his behavioral symptoms and applying the synthesized theory of Klein, Fairbairn and Winnicott's object relations within the general theoretical framework of psychoanalysis to identify the psychological root causes. It is noted in this study that concentrating on behavioral symptoms in order to investigate Jed's behaviors in this selected fiction is the most relevant means since, as Searle (2004) believes, in analyzing and exploring an individual's mind, the "only evidence we have for the other minds is behavior". It is in this psychoanalytic context that this study investigates Jed in Enduring Love. The symptoms as evidenced from his behavioral pattern - a certain passionate desire for union with the other character, Joe, as a love object that fails to materialize at the crucial moment due to a weakened ego, conflicts and anxieties because of an inability to establish a healthy set of relationships. It is found that Jed who suffers from a not good-enough mothering, develops into a psychologically and emotionally less than normal adult with conflicts, anxieties and a weakened ego that is reflected in low self-esteem and a general lack of self-confidence, and therefore, seeking love in Joe. All these are clear instances of McEwan's characters failing to bring a relationship to fulfillment because of their psychological and emotional inadequacies. Through the lens of the Klein, Fairbairn and Winnicott theory of object relation, we suggest the causes for such conflicts and anxieties of these characters and conclude that they are the result of a failure to relate satisfactorily to their respective primary caregivers in their early childhood.

To investigate psychoanalytically the behavioral symptoms of Jed in Enduring Love, and to attribute these explanations to the Klein, Fairbairn, and Winnicott theory of object relations, it needs to be noted that these theorists "usually center on the early relations of a child and mother" and hence, strongly believe that "this early relationship shapes the child's inner world and later adult relationships" (Clair, 1986). Klein, Fairbairn, and Winnicott, through their object relations theory, "investigate the early formation and differentiation of psychological structures (inner images of the self and the other, or object) and how these inner structures are manifested in interpersonal situations" (Clair, 1986). They center mainly on "the relationships of early life that leave a lasting impression; that is, a residue or remnant within the psyche of the individual. These residues of the past relationships, these inner object relations, shape perceptions of individuals and relationships with other individuals" (Clair, 1986). These theorists believe that "individuals interact not only with an actual other but also with an internal other, a psychic representation that might be a distorted version of some actual person" (Clair, 1986).

Our adult world, in Klein's terms, is considerably influenced by our childhood experiences with our primary love 
objects, particularly with the mother. Klein believes that in order to study "the behavior of people in their social surroundings, it is necessary to investigate how the individual develops from infancy into maturity" (Klein, 1959). According to object relation models, "successful establishment of good object relations in early childhood leads to normal and healthy development, and the crucial determinant of later pathology is when the child during the phase of infancy fails in his efforts to establish good object relations" (Eklund, 2000). As a result, in order to have "an exploration of the individual's development", the psycho-analyst needs to "takes back, by gradual stages, to infancy" (Klein, n. d.).

As Klein (1959) puts it, "if we look at our adult world from the viewpoint of its roots in infancy, we gain an insight into the way our mind, our habits, and our views have been built up from the earliest infantile phantasies and emotions to the most complex and sophisticated adult manifestations". Klein believes that "nothing that ever existed in the unconscious completely loses its influence on the personality", particularly the experiences and the links which "are found in the relation to the primal good object, the mother, whatever may be the forms in which distortions of character are accepted and even admired" (pp. 262-263). Therefore, Klein asserts that, "at the core of memory, then, lies the mother who is perceived as a physical body that gratifies, accepts, protects, understands and loves" (Gurac, 2007). And accordingly it needs to be noted that the emphasis on this child-mother love is considered as one of the most significant contributions of object-relations theory to psychoanalysis. This belief proposes that "our emotional make-up and our relations to ourselves and others are shaped by this early love bond between the infant and the mother". On this matter, "object-relations theory assumes that human psychic life begins with the infant's relation to his mother - and, although this is an exceptionally complex relationship, it is shaped by one persistent need on the part of the infant: the need to be loved by the mother. At this early stage, love provides the vital emotional nourishment the infant needs to survive and grow" (Gurac, n. d.). Hence, for the child, to obtain this mother's love from the mother who "gratifies, accepts, protects, understands and loves" represents to be alive.

Klein, Fairbairn, and Winnicott focused basically on the relationship between mother and infant, particularly during the first year. They posit that this primary relationship between the mother and the infant is the most important factor which leaves a lasting effect on the child's mind even into adulthood. They emphasize that experiencing a 'good-enough' mothering situation during the infantile stage, signifies that the child will experience a healthy development and healthy life in his adulthood, whereas "inadequate parenting" as Fairbairn states, "poses grave threats to the integrity of the ego" (Mitchell, 1981). These selected object relations theorists give greater attention to this matter to explain how a person (a child) develops a self through relationships inside a family - particularly with the mother, and how this self in turn relates in a distinctive way toward others. Generally, their interest is in studying the disorders in relationships.

Klein, Fairbairn, and Winnicott "have traced the psychological make-up of the individual to its origins in the first weeks and months of life" (Albiston, 1983). They all believe in "the profound importance of the maternal environment" and generally "agree that the infant's relationship to his objects (parental figures) sets the cast of personality structure and character within which life's drama, through all of its stages, unfolds" (Albiston, n. d.). There is a prevalent acknowledgment among Klein, Fairbairn, and Winnicott that the quality of the child's interaction to the mother-and, eventually, other people - is influenced by the child's capability to sustain a stable representation of his maternal figure.

Therefore, in the following analysis, we attempt to show how the residues of Jed's childhood relationships with his primary love objects are significant for the mode the narrative fits together, and how to some extent those childhood representations come to merge the theme of the story. Hopefully, we will also show that the modes in which those childhood representations are significant for this narrative are not at all times palpable and direct. Consequently, the point for me is "to infer presence from absence" (Adams 2004).

\section{Discussion}

\section{1 Jed's Not Good-enough Mothering and His Infantile Dependency}

The term "good-enough mother", was coined by Winnicott to explain the parental function of providing adequately for the child to get a good beginning in his/her life and this "maternal care in various types...determines at a very early age the patterns of the defenses of the individual, and also gives the blueprints for later sublimations" (2005). In Winnicott's discussion, “"good enough' refers to a constellation of qualities of care. It includes an awareness of the psychological and physical needs of the infant and implies a consistent, reliable and predictable response to the infant's needs" (Stiefel et al., 1998). In fact, Winnicott (2005) declares that, "the initiation of a relationship between the child and the world is made possible by good-enough mothering at the early critical phase". The 'good-enough mother', based on Winnicott's views, is a mother who adapts to 
her infant appropriately at different stages of his development. This helps and allows him an optimal environment to develop as a separate individual, and finally to be capable of mature object relations.

The infant, then, in order to have a healthy development, needs to have a healthy environment around himself. Maternal care is in fact the essential factor in environment. Winnicott states that "the mother herself, at first, is the facilitating environment" and the environment of maternal care (Winnicott, 1963). Therefore, Winnicott draws attention constantly to the role of the maternal environment and states that when the environment [maternal provision], is good-enough, it facilitates the process of maturation in the infant. When the infant grows up, he gradually depends less on the environment or mother. Hence, in an environment of good-enough mothering, the child develops, and starts progressing for object relationships, that is to say, relationships with the whole external object.

Consequently, Winnicott (1960) discusses, owing to the success in maternal care, there is developed in the infant a "continuity of being, which is the basis of ego-strength; whereas the result of each failure in maternal care is that the continuity of being is interrupted...with resultant ego weakening". Therefore, as Winnicott declares, "a sense of 'going to pieces', of falling forever, of having no relationship to the body and of having no orientation are the varieties of the massive anxiety accompanying the failure of the early maternal care environment" (Albiston, 1983).

In Enduring Love, Jed, like a "child" (Enduring Love, p. 67), and as a dependent character, is always willing to attach to an external loved object to achieve support and gratification. This need for attachment, to relate to the desired object is constant in Jed. According to Winnicott's idea, through the infant's needs (met and confirmed by the mother), the infant discovers "the environment and the not-me world", the internal and external world (Clair, 1986). This basic procedure forms the relationship between the child and his world.

Through the various parts of the selected novel, it can be seen that Jed does not experience emotional gratification. That is why he is perpetually struggling to seek the idealized loved object (here Joe) - a need developed from unhappy childhood days. It is clear here that McEwan is hinting at the state of his male character's dependency on the loved object. Jed's neediness, yearning, and dependency on a loved object forms the basis of his perpetual search for the loved object. The reappearance of the same images of Jed's unsatisfactory relationships with his loved object implies that what Jed's psychological disabilities and anxieties are dealing with is his childhood reminiscence of not good-enough, "unsupportive" (Enduring Love, p. 236) mothering which is still influencing his set of interactions with loved characters in his adulthood. The reappearance of this image suggests that the object which has caused these anxieties for Jed through the various parts of the novel has been supposed and characterized in his psyche as the representation of his not good-enough mother.

The "maturational process" in Jed, due to experiencing a not good-enough maternal environment, has been shaken, because "at first", as can be understood from the perspective of Winnicott who states, "it is the mother herself who is the facilitating environment" (Winnicott, 1965). In Winnicott's remarks, "the environment (in the person of the mother) when it is good enough, facilitates the maturational process of the infant" (Clair, 1986). Therefore, it might be suggested that Jed's lack of ego development has its roots in his unsatisfactory childhood anxieties owing to experiencing an "unsupportive mother" with whom "he had virtually no contact with" and an absent "father" (Enduring Love, p. 236) all through his childhood. Jed has not been enabled to possess, through the lens of Klein, "an internalized good parent" (Klein, 1975b), a good enough primary care giver within his psyche, to lead him towards maturational development. Winnicott believes that it is mostly this lack of facilitating environment, unsatisfactory maternal situations, and absence of emotional assurance that heavily influences our adult reactions. Concerning the residues of these emotional breakdowns in the individual's psyche, Winnicott (1986) indicates that:

children do not remember when things went well, they remember when things went wrong, because they remember that suddenly the continuity of their life was snapped, and their neck went back or something, and it came through all the defenses and they reacted to it, and this is an extremely painful thing that has happened to them, something they cannot ever lose (our emphasis)

These early painful experiences with the primary caregivers during the childhood, as "something they cannot ever lose", stay in the individual's psyche and lead him towards a state of dependency and obsession in his adulthood upon his adult external objects. As a consequence, facing a sense of "falling forever" in having and establishing a healthy set of relationships with the other external objects is a painful experience that the individual will meet, and therefore, it is stated that these senses, as Winnicott indicates, "are varieties of the massive anxiety accompanying the failure of the early care environment" (Albiston, 1983, our emphasis). 
The nature of Jed's perception of the loved characters in his adulthood signifies the state of his perception of his childhood experiences of the situation of not good-enough mothering (his first loved object) in his childhood, because as the selected object relations theorists in the present study argue, our adult interactions have their roots in our childhood. Identifying Jed's neediness heralds what Klein calls "adult world and its roots in infancy" (Klein, 1975b). In Klein's terms, our adult world is considerably influenced by our childhood experiences with our primary love objects, particularly with the mother. Klein believes that in order to study "the behavior of people in their social surroundings, it is necessary to investigate how the individual develops from infancy into maturity" (Klein, 1975b). Therefore, in order to have "an exploration of the individual's development", the psycho-analyst needs to "takes back, by gradual stages, to infancy" (Klein, 1975b). As Klein puts it "if we look at our adult world from the viewpoint of its roots in infancy, we gain an insight into the way our mind, our habits, and our views have been built up from the earliest infantile phantasies and emotions to the most complex and sophisticated adult manifestations" (Klein, 1975b). According to Klein "nothing that ever existed in the unconscious completely loses its influence on the personality", particularly the experiences and the links which "are found in the relation to the primal good object, the mother, whatever may be the forms in which distortions of character are accepted and even admired" (Klein, 1975b). As a result, Klein asserts that, "at the core of memory, then, lies the mother who is perceived as a physical body that gratifies, accepts, protects, understands and loves" (Gurac, 2007).

The different parts of the novel imply that Jed's experiences both in his childhood and adulthood bring him anxieties and tensions rather than gratifying feelings. The imagery of Jed's state of dependency, his desperate attachment to Joe, his yearning for love and emotional satisfaction, and his need for being accepted and loved can be perceived and read as a narrative interpretation of an emotionally hungry, dependent child and his desire towards a yearned-for maternal support. Joe, regarding his ideas on Jed's dependency, says that Jed was "a man bound to me" (Enduring love, p. 58). Jed is, as Clarissa says, "a lonely inadequate man... who is probably living off his parents, and dying to connect with someone, anyone, even Joe" (Enduring love, 81, our emphasis). Within the story we find that Jed, during his childhood, has been "an intense and lonely child" with an "unsupportive mother", a father who passed away the time Jed was eight years old, and an "untraceable" sister who had "moved abroad and he never saw her again" (Enduring Love, p. 236).

After the death of his "unsupportive mother", Jed alone, who, as the story suggests, had been disabled to have an introjection of the good objects, to borrow Klein's phrase, and hence, completely deprived of good-enough emotional assurance from his primary love objects in his childhood, chooses to move into his late-mother's dwelling "where both his isolation and his religious beliefs intensified" (Enduring love, p. 237) and "his isolation was complete" (Enduring love, 241). Therefore, his failure to experience a situation of good-enough mothering raised him as a dependent and emotionally impoverished individual who failed to grow out of his infantile dependency and consequently yearns perpetually for love and emotional assurance from his external objects. Jed's internal desires and desperate needs for receiving love, emotional provision, and having satisfactory connections has been voiced by Joe saying that "the pattern of his [Jed's] love was not shaped by external influences, even if they originated from me. His was a world determined from the inside, driven by private necessity, and this way it could remain intact" (Enduring Love, p. 143, our emphasis). Based on Joe's indications and particularly his emphasis on Jed's "inside" and "private necessity", suggest Jed's unsatisfying early object relationships and his failure to experience a good-enough maternal care throughout his childhood, and therefore, having roots in his "inner" world of infantile frustrations and anxieties.

Jed's situation fits right into Fairbairn's arguments on the emotional needs of a child. He comments on this situation and indicates that "the greatest need of a child is to obtain conclusive assurance (a) that he is genuinely loved as a person by his parents, and (b) that his parents genuinely accept his love". Therefore, "it is only in so far as such assurance is forthcoming in a form sufficiently convincing to enable him to depend safely upon his real objects that he is able gradually to renounce infantile dependence without misgiving." Furthermore, Fairbairn (2001) believes that "in the absence of such assurance his relationship to his objects is fraught with too much anxiety over separation to enable him to renounce the attitude of infantile dependence."

Jed's extreme devotion to religion might be likewise interpreted in terms of a substitute for his isolation and neediness while moving alone into his "unsupportive", dead mother's home where he experienced an entire and absolute isolation. Within the story we detect that Jed's "relationship with God was personal, and served as a substitute for other intimate relationships" (Enduring Love, p. 241, our emphasis) with his external objects in his adult interactions. According to Fairbairn, the child, as a result of experiencing a lack of sufficiently convincing emotional assurance from his parents, will be unable to renounce his attitude of infantile dependency, and therefore, attempts to compensate this failure and missing emotional support by the agency of dealing with some 
types of substitute satisfaction which, in Fairbairn's words, these "substitute satisfactions compensate for the failure of emotional relationships with other objects". Fairbairn indicates that "these substitute satisfactions represent relationships with internalized objects; the individual turns to them instead of safe and satisfactory relationships with objects in the outer world" (Clair, 1986).

We contend that this extreme attachment to religiosity, for Jed, is in fact a type of substitute satisfaction which signifies his lost good-enough emotional interactions with his primary care givers. Jed's intense religious devotions, psychoanalytically, might be read as his unconscious desperate need for love and emotional support from his lost maternal figure. For Jed, who "listened only to the inner voice of his private God" (Enduring Love, 153), this "inner voice" might be argued as the voice of his primary internal damaged love bond which has been exemplified and re-enacted in such a painful dependency, attachment, and emotional breakdowns all through his relationships with his external objects which are filled with psychic anxieties and tensions.

\subsection{Jed's Perpetual Search for His Idealized Lost Love Object}

Unsatisfactory primary experiences in his childhood with his "unsupportive mother" as his primary love object has probably been, in Klein's idea, the root cause of Jed's failure in his adult object relationships and this situation has probably made him an emotionally hungry individual who has been engaged in a memorial search for his internal idealized love object. Experiencing a not good-enough facilitating environment, has impacted Jed's later interactions, and therefore, he has not been enabled to incorporate a good-enough maternal figure deep in his psyche. Hence, he searches for an equivalent love object to satisfy him emotionally and gives him the love and support he once has missed all through his early life. This situation in Jed's life indicates a critical failure of his development from infantile dependency to adult independence.

Jed, being desperately attached to and dependent on Joe, and due to his infantile attitude of dependency, identifies with him as his idealized love object. To abandon his primary ungratifying experiences with his primary care giver, Jed assumes Joe as an equivalent love object to his primary incorporated love object, and hence, his needs and emotional desires have been voiced and projected towards Joe. In Fairbairn's terms, "the abandonment of infantile dependence involves an abandonment of relationships based upon primary identification in favor of relationships with differentiated objects" (Fairbairn, 2001). This process of "primary identification in favour of relationships with differentiated objects" is a significant feature during the childhood.

Fairbairn believes that "the process of differentiation of the object derives particular significance from the fact that infantile dependence is characterized...by identification...In virtue of this fact the object with which the individual is identified becomes equivalent to an incorporated object" (Fairbairn, 2001). As a result, Joe (a differentiated object), who has been identified with, becomes an equivalent to Jed's primary incorporated object. Therefore, Jed's desperate yearning to establish a relationship with Joe (who is perceived as an internal idealized love object by Jed) is actually indicative of his primary "frustration or increased anxiety", and also his failure at achieving a genuine connection with his own primary care givers, of his "lifetime's failure to form close relationships" (Enduring Love, p. 239), particularly with his mother and father and even his only "untraceable" sister.

Regarding the above mentioned issues, Jed's craving for establishing a relationship with Joe can be read as a narrative account of a perpetual search for his idealized lost love object. Klein also comments on this situation and states that "one characteristic feature of the earliest relation to the good object (first of all, the mother's breast) - internal or external - is the tendency to idealize it" (Klein, 1975b). Hence, "in states of frustration or increased anxiety", Klein believes that, "the infant is driven to take flight to his internal idealized object as a means of escaping from persecutors" (Klein, 1975b). In Jed's behavior (his state of infantile dependency and his anxiety evoking object relations) there are echoes here of Klein's belief that through experiencing unsatisfactory object relationships "the flight to the idealized object becomes excessive, and this severely hampers ego-development and disturbs object-relations" (Klein, 1975b). What happens here, as a result, fits the incidents which have occurred for Jed. Klein, concerning the result of excessive searching for the idealized object, indicates that, "as a result the ego may be felt to be entirely subservient to and dependent on the internal object" (Klein, 1975b), and Klein's statement fits Jed's state of object relations with his supposedly perceived internal idealized love object (Joe). Therefore, Klein believes that, if the conflict over frustration or increased anxiety within the external or internal object relationships is not resolved, a person may be unable to adapt to other sources of comfort. For this reason, the person all through his life will not be capable of unifying all these emotional relationships in one whole object. As a result, he will be always looking for a loved object. Consequently, he may not be able to adapt himself truly to any other frustrations which follow in life (Klein, 1975a). 
When "the child", in Klein's arguments, "starts to relate to the external objects this is a paradigm for him to develop his relationships in the outer world. This system develops healthily if there are good maternal care and provisions by the mother". Hence, "if a child has good-enough mothering, the transfer position is done healthy and child can achieve independency and a normal life. Otherwise, the child grows with a dependent character and always looking for someone to replace the role of the mother for him" (Shakouri, 2008). Hence, Jed, with unresolved internal conflicts and anxieties still searches for an ideal external object to attach to in order to fulfill his desperate needs for lost emotional assurance, love, and comfort.

In case the child does not succeed in introjection of this first whole good object (resulting from his experiencing a situation of not good-enough facilitating environment) he will fail, as Klein remarks, at unifying the loving and hating aspects of his first whole good object. Therefore, during his adulthood he will be unable to create a healthy relationship with others; he will not be able to integrate and accept both good and bad aspects of the others in them. So, "alternately, or simultaneously, there may be a flight to the [first] idealized loved object" (Segal, 1981). Jed suffers from a weakened ego that is probably the result of not good-enough maternal provisions in his childhood. He is a male character who has not had healthy introjections of the primal ideal loved object in his childhood. As such, he is searching and striving endlessly for his ideal loved objects even in his adulthood.

Winnicott also comments that, through the infant's needs (met and confirmed by the mother), the infant discovers "the environment and the not-me world", the internal and external world (Clair, 1986). This basic procedure forms the relationship between the child and his world. Through the various parts of the novel, it can be seen that Jed does not experience emotional gratification. As a dependent character with the residues of not good-enough maternal experiences, Jed, "like a curious child" (Enduring Love, p. 67), is constantly willing to attach to an external loved object to achieve support and gratification. Notwithstanding the lack of reply from his supposedly love object (Joe), he still desperately writes Joe saying that "the thousandth day, my thousandth letter...this happiness is almost an embarrassment to me...I adore you. I live for you. I love you" (Enduring love, pp. 244-245). In fact, as Clarissa expresses, Jed is merely "a lonely inadequate man who is...dying to connect with someone, anyone" (Enduring love, 81, our emphasis). This imagery suggests that Jed's need for connection, to relate to the desired object is constant in him. That's why he is perpetually struggling to seek the idealized loved object - a need developed from unhappy childhood days.

In sum, Jed keeps suffering from insufficient maternal care and lack of introjection of his primary loved object in his childhood. As such, his anxieties and tensions in his struggle to find a loved object originate from his need to be accepted, and loved. However, reading Enduring Love, we come to believe that, there is no reprieve for Jed. He has consistently failed all through his life in his relationships with his primary love objects (mother, father, sister), and even in the last lines of the story ("I live for you. I love you"), we feel a sense of sadness for Jed whose love song will always be a process of enduring a sad song of love.

\subsection{Jed's Aggressive Inclinations}

The traumatic relationships that Jed has established with Joe in Enduring Love, we suggest, are rooted in his early, unsatisfying object relationships, and throughout the novel the adult Jed's aggressive tendencies towards Joe originate in his childhood anxieties and frustrations and now these tendencies are the attempts he performs to cope with his relational difficulties. The anxiety that Jed feels through his interactions with Joe is acted out as overt violence towards Joe which is communicated in his final aggressive actions through sending troubling and sometimes threatening letters, giving lots of frustrating phone calls, and finally, threatening Clarissa and hiring some persons to shoot at Joe. Jed's aggressive tendencies towards Joe (perceived as his libidinal love object) is interpreted in fact as a representation and re-enactment of his own ungratifying early object relationships with his primary care givers and the frustrations he had experienced as a result of their depriving love and support.

In Klein's, Winnicott's, and Fairbairn's terms, the mother is the first and primary libidinal object for the child and her satisfying or unsatisfying interactions with the child severely impact on the child's later relationships with the other external or internal libidinal objects. According to Fairbairn, "the ultimate aim of the ego is to have an object to love and to be loved by, to establish a meaningful emotional relation with an object, to invest his love in and to grow with" (Gurac, 2007). Once this love bond is shaken, the child's emotional life becomes traumatic and aggressive, and his ego becomes weak and undeveloped. Fairbairn regards "aggression as a primary dynamic factor" (Fairbairn, 2001) and indicates that "aggression is a significant part of infant's emotional life....and it is present in the psyche from the very beginning [the birth, since the birth itself is anxiety provoking]" (Gurac, 2007). Therefore, the mother's ungratifying and depriving relationships give rise to the child's aggression and in the other words, as Fairbairn argues, "aggression is not an innate quality of the ego but an emotional response to 
libidinal deprivation" (Gurac, 2007).

In Fairbairn's words, it is "the imperfect conditions of life that disturbs the libidinal relationships of the infant to its mother, and prompt the infant to respond through various defensive mechanisms that contribute to the building up of the internal structures" (Clair, 1986). Fairbairn continues that the degree of frustration differs in individual cases, but indeed "it is the experience of libidinal frustration that calls forth the infant's aggression in relation to his libidinal object" (Fairbairn, 2001). Therefore, as Fairbairn indicates, "aggression is not a primary motivational factor. Rather than arising spontaneously, it is a reaction to the frustration of the primary motivational aim- the striving for contact with objects" (Greenberg, J., \& Mitchell, S., 1983). Consequently, Fairbairn considered aggression as an effect of the lack of gratifying object relationships and as a consequence of deprivation through which "the infant responds to the frustration with aggression and takes in or internalize the problematic object" (Clair, 1986), and this primary frustrating and depriving internalized love object becomes the prototype of the individual's aggressive tendencies in his later interactions with the other external or internal objects.

Jed, like a dependent "child", perceives Joe as his libidinal lost love object and expects him (Joe) to accept his love. Receiving no love response from his libidinal object (Joe) gives rise to Jed's aggression and frustration, and this aggression, as I find based on Klein and Fairbairn ideas, has its roots in Jed's own frustrating experiences with his primary love objects. In Jed's aggression there are echoes of Fairbairn's belief that insufficiency of love is the root causes of aggression and anxieties for the child. Fairbairn remarks that the child needs to be loved, obtain emotional assurance, and his love to be accepted (Fairbairn, 2001). In case such emotional assurance is or not good-enough then the child's "relationship to his objects is fraught with too much anxiety over separation to enable him to renounce the attitude of infantile dependence; for such a renunciation would be equivalent in his eyes to forfeiting all hope of ever obtaining the satisfaction of his unsatisfied emotional needs" (Fairbairn, 2001).

It is only this emotional support and assurance that helps the child to grow out of his infantile dependency. Failure to receive such love and emotional support causes the child's aggressive, dependent, and weakened ego. Then, unsatisfying love object becomes internalized in the child's psyche as representing all his later bad, unsatisfying objects in his adult life. As Fairbairn states, these internalized objects are "dynamic", "capable of acting as independent agencies within the mind", and of psychological activity during his entire adult object relationships (Fairbairn, 2001). Later in his life, this frustrated, emotionally deprived child might get involved in other object relationships where they are again victims of emotional frustrations.

Relying on Fairbairn's comments concerning the root causes of aggression, we see an emotionally hungry and frustrated child buried in Jed. Fairbairn believes the result of receiving no emotional response from the libidinal (love) objects leads to the substitution of hate for love and therefore, aggression. An emotionally hungry and dependent individual, in Fairbairn's terms, who does not attain emotional assurance from his love objects "often he often takes active measures to drive his libidinal objects away from him. For this purpose he has an instrument ready to hand inside himself in the form of his own differentiated aggression. He mobilizes the resources of his hate, and directs his aggression towards others -and more particularly against his libidinal objects" (Fairbairn, 2001, our emphasis). Therefore, "in so doing, he not only substitutes hate for love in his relationships with his objects, but also induces them to hate, instead of loving him [struggle between love and hate]" (Fairbairn, 2001).

As we interrogate Jed's situation, we see that Jed is an individual who has experienced not good-enough maternal situation which has caused him to fail at growing out of his infantile dependency and the tragic consequences that ensue. Jed as an emotionally hungry and dependent individual has not received an emotionally satisfying love response from his perceived love object (Joe). This lack of love response leads him to utilize the "instrument ready to hand inside himself" in the form "aggression". Jed, therefore, mobilizes the resources of his hate, (to borrow Fairbairn's terms) and directs his aggression towards Joe as his perceived "libidinal objects". He starts threatening Joe saying him that he can hire some people to beat Joe and Joe considers his (Jed's) words seriously as "being threatened" (Enduring Love, 129). Jed warns Joe that "I'm pretty well off you know. I can get people to do things for me. Anything I want. There's always someone who needs the money. What's surprising is how cheap it is, you know, for something you'd never do yourself" (Enduring Love, pp. 129-30). He keeps sending Joe many disturbing, "generally long and ardent" letters, "three or four letters a week" (Enduring Love, 141). Jed's letters were sometimes threatening, as Joe says, and warning Joe that "I wanted to hurt you. Perhaps even more than that" (Enduring Love, pp. 151-152), or threatening Joe that "God's love...may take the form of wrath" (Enduring Love, p. 152), whereas, as Joe says, this "God was a term interchangeable with self. God's love for mankind shaded into Parry's love for me" (Enduring Love, p. 152). And finally, Jed's aggression towards Joe was communicated in the form of threatening Clarissa, "listen carefully now; Parry [Jed] said. Here 
she [Clarissa] is. Joe? I knew immediately she was frightened. Her voice was pitched high" (Enduring Love, p. 204).

Jed, through his aggressive and destructive tendencies towards Joe, in fact, based on Fairbairn's words, has induced Joe to hate him, instead of loving him and finding him as a hateful "fixated" "ridiculous guy" (Enduring Love, 86). Jed attempts to destroy Joe, "the very person who is the object of all his desires" (to borrow Klein's words), and has altered his love feelings into hated ones towards him. Melanie Klein, concerning the root causes of this "struggle between love and hate", states that the mother is "the baby's first object of love and hate". It is the "mother" who is "both desired and hated" (Klein, 1975a). According to Klein, in the very beginning, the child loves his mother "at the time she is satisfying his needs" and is "giving him the sensual pleasure" (Klein, 1975a). But when the child's "desires are not gratified, or when he is feeling...discomfort, then the whole situation suddenly alters. Hatred and aggressive feelings are aroused and he becomes dominated by the impulses to destroy the very person who is the object of all his desires and who in his mind is linked up with everything he experiences - good and bad alike" (Klein, 1975a, our emphasis).

In consequence, "love and hate", as Klein indicates, "are struggling together in the baby's mind; and this struggle to a certain extent persists throughout life and is liable to become a source of danger in human relationships" (Klein, 1975a, my emphasis). Therefore, this process of love-hate struggle in Jed (who has experienced a situation of having an "absent" father and an "unsupportive mother" in his childhood), throughout his adult life, might have its root causes in Jed's early unsatisfying primary object relationships with his not good-enough primary care givers, since Klein remarks that, this "struggle between love and hate" in the child, "starts with the child's relationships to both parents" and as a result "is active all through life" (Klein, 1975, my emphasis).

\section{Conclusion}

All through this investigation, the conclusion has been drawn by inference and comparison, matching various aspects of the Klein, Fairbairn, and Winnicott's theory of object relations to clearly identified behavioral symptoms of the characters rather than the other way round. This indicates that in this interpretation, care has been taken to ensure that clearly identified behavioral symptoms are explained by possible and probable psychological reasons and not vice versa. Employing this conceptualization has enabled us to conclude that the failure of Jed Parry in Enduring Love to establish satisfactory and lasting relationships with the others is due primarily to his unsatisfactory child-mother relationships in his early childhood which in his adulthood, are manifested in his lack of self-confidence from a weakened ego, which in turn creates conflicts and anxieties in his psyche that hamper his relationships with the other characters.

As a matter of fact, the current psychoanalytical research on Enduring Love could be argued as a testimony to the critical impact of the residues of the primary child-mother interactions of the individuals on their current adulthood life. These residues and intimations of such interactions are considered as a re-enactment and representation of the primary parent-child relationships in Enduring Love, however, this is a type of relationship which is not immediately palpable, for the reason that it is masked by the main characters of the novel that implicitly support this psychoanalytical interpretation.

It is important to note that in studying McEwan's characters in Enduring Love, from a psychological point of view, we attempt to attribute the behavior of the characters to their early childhood relationship problems. Although sometimes there is no actual textual mention of the characters' early childhood, however, to avoid being accused of presumption and hypothetical guesswork, we took the caution of approaching character analysis of Enduring Love by first carefully identifying the behavioral symptoms before attributing pre-adulthood psychological circumstances for such symptoms. Consequently, the conclusions in this study are drawn by inference and comparison, matching various aspects of the Klein-Fairbairn-Winnicott theory of object relation to clearly identified behavioral symptoms of the characters rather than the other way round. This indicates that in this study, care has been taken to ensure that clearly identified behavioral symptoms are explained by possible and probable psychological reasons and not vice versa. Such an approach has enabled us to conclude that the failure of the characters in Enduring Love to establish satisfactory and lasting relationships with each other is due primarily to their unsatisfactory child-mother relationships in their early childhood which in their adulthood, are manifested in their lack of self-confidence from a weakened ego, which in turn creates conflicts and anxieties in their psyches that hamper their relationships with the other characters.

In conclusion, we emphasise that Enduring Love is concerned with the memory and sensation of the mother. The adult characters, Joe, Jed, Clarissa are in fact perpetually looking for the love object, attempting to linger on being attached to her. These adult characters are not merely seeking any mother. They are searching for the gratifying, good-enough mother, the mother by whom they are enabled to "obtain the satisfaction" of their 
"unsatisfied emotional needs". As a result, Enduring Love makes our infantile memories attainable to us all over again. Fairbairn, Klein, and Winnicott's theory of primary object relationships illustrate for us the mother whom we deeply adore and the child that we are. All through in our adulthood, McEwan's Enduring Love may takes us to the point of "enduring" our primary love bond and experiencing our infantile needs in regard with our primary gratifying loved object.

\section{References}

Adams, J. (2004). On the Significance of Children in Ian McEwan's Enduring Love. Retrieved June 10, 2014, from http://www.lse.ac.uk/economicHistory/Research/facts /The\%20Significance\%20of\%20Children.pdf

Albiston, R. K. (1983). The Advent of Object Representation: A Piagetian Critique of the British School Theorists: Klein, Fairbairn, Winnicott and Guntrip. Diss. Tennessee University.

Byrnes, C. (1995). Sex and sexuality in Ian McEwan's work. Nottingham: Paupers' Press.

Byrnes, C. (1999). The Work of Ian McEwan: A Psychodynamic Approach. Diss. Newcastle University.

Cameron, O. (2002). A Lacanian look at English elegance: some reflections on Ian McEwan's Enduring Love. The International Journal of Psycho-analysis, 83, 1153-1167. http://dx.doi.org/10.1516/69DY-3T45-YBEV $-\mathrm{AQH} 4$

Clair, M. St. (1986). Object Relations and Self Psychology: An Introduction. California: Brooks/Cole Publishing.

Cowley, J. (1997). The prince of darkest imaginings. The Times, Interview, 6 Sept.

Eklund, M. (2000). Applying object relations theory to psychosocial therapy. Occupational Therapy in Mental Health, 15(1), 1-26. http://dx.doi.org/10.1300/J004v15n01_01

Fairbairn, W. R. D. (2001). Psychoanalytic Studies of the Personality. London and New York: Routeledge Publishing.

Fitriya, L., \& Khoiri, D. M. (2014). Briony's guilty feeling and her atonement in Ian McEwan's Atonement. Language Horizon, 2(1), 0-216.

Greenberg, J., \& Mitchell, S. (1983). Object Relations in Psychoanalytic Theory. Cambridge, Massachusetts: Harvard University Press.

Gurac, S. (2007). A long Night's Journey into the Mother: A Psychoanalytic Study of T.S.Eliot's Early Poems. Diss. Lehigh University.

Keating, S. (2003). Loss, illusion systems of defence and possible reparation in two works by Ian McEwan. Free Associations, 10, 283-330.

Klein, M. (1959). Our adult world and its roots in infancy. In M. M. R. Khan (Eds.), Envy and gratitude and other works 1946-1963. London: Hogarth Press.

Klein, M. (1975a). In M. M. R. Khan (Eds.), Love, Guilt and Reparation and Other Works 1921-1945. London: Hogarth Press.

Klein, M. (1975b). In M. M. R. Khan (Eds.), Envy and Gratitude and Other Works. 1946-1963. London: Hogarth Press.

Kogan, I. (2012). Ian McEwan's Solar through a psychoanalytic lens. Journal of the American Psychoanalytic Association, 60, 1299. http://dx.doi.org/10.1177/0003065112465470

McEwan, I. (2004). Enduring Love. UK: Vintage Books.

Mitchell, S. A. (1981). The origin and nature of the object in the theories of Klein and Fairbairn. Contemp. Psychoanal, 17, 374-398. http://dx.doi.org/10.1080/00107530.1981.10745670

P.H.S. (1997). New penny. The Times, Interview, 18 Sept.

Seaboyer, J. A. (1997). Second death in venice: cognitive mapping in the venetian fictions of Jeanette Winterson, Ian McEwan, and Robert Coover. Ph.D thesis. University of Toronto.

Searle, J. (2004). Mind: A Brief Introduction. New York: Oxford UP.

Segal, H. (1981). Melanie Klein. New York: Penguin Books.

Sgarlata, E. (2009). Desire versus conscience: development of the id and ego in Ian McEwan's fiction. MA thesis. Baylor University.

Shakouri, S. (2008). Object Relation Psychoanalytic Criticism on Selected Works of Tennessee Williams. Diss. 
University Putra Malaysia.

Slay, J. Jr. (1991). A prevailing ordinariness: Society and interpersonal relationships in the fiction of Ian McEwan. Ph.D thesis. Tennessee University.

Stiefel, I., Harris, P., \& Rohan, A. (1998). Object relations family therapy: articulating the inchoate. A.N.Z.J. Fam. Ther, 19(2), 55-62. http://dx.doi.org/10.1002/j.1467-8438.1998.tb00314.x

Vipond, L. (2008). How to read the unreadable: A post-structuralist approach to the works of Ian McEwan. Final year thesis. University of Edinburgh.

Wilks, L. (2009). Loose morals and sex maniacs, childhood memories and interpretations of sexual desire in Atonement. Cinemascope Independent Film Journal, 13.

Winnicott, D. W. (1960). The theory of the parent-infant relationship. Maturational processes and the facilitating environment. London: Hogarth Press.

Winnicott, D. W. (1963). From dependence towards independence in the development of the individual. Maturational processes and the facilitating environment. London: Hogarth Press.

Winnicott, D. W. (1965). The Maturational Processes and the Facilitating Environment: Studies in the Theory of Emotional Development. London: Hogarth Press.

Winnicott, D. W. (1986). Home is Where We Start From: Essays by a Psychoanalyst. New York: W. W. Norton \& Co.

Winnicott, D. W. (2005). Playing and reality. London and New York: Routledge.

\section{Copyrights}

Copyright for this article is retained by the author(s), with first publication rights granted to the journal.

This is an open-access article distributed under the terms and conditions of the Creative Commons Attribution license (http://creativecommons.org/licenses/by/3.0/). 